\title{
Jackie Feldman A Jewish Guide in the Holy Land: How Christian Pilgrims Made Me Israeli
} (Bloomington: Indiana University Press, 2016), soft cover, xii + 205 pp.

\author{
DEBORAH WEISSMAN \\ debbiew@netvision.net.il \\ International Council of Christians and Jews, 64629 Heppenheim/Germany
}

In $2015,56 \%$ of the visitors to the state of Israel were Christian. Not all of them would have described the visit as a trip to "Israel"; some would call it "the Holy Land"; others would say "Israel / Palestine." A diverse group, denominationally, geographically, and culturally, these Christians pose many challenges to the largely Israeli-Jewish guides and lecturers who work with them. First, like many of their fellow countrymen and women, the guides tend to be quite ignorant about the New Testament and Christianity, except for the requisite brief introduction they received in their government-sponsored training course. Second, some of them may still possess traditional Jewish anti-Christian attitudes, grounded in the unfortunate shared history of the two communities, and may not be aware of recent positive developments in Jewish-Christian relations. Third, many of them are either Orthodox Jews or dyed-in-the-wool secularists, with their own strong views.

As a licensed guide, Dr. Jackie Feldman has excellent credentials to investigate "how Jews [who guide Christians] react to faith experiences whose objective nature they deny" (p. 148). A guide who has years of experience working with Christians, he brings to study of this topic a valuable combination of his personal background as a traditional Jew, his academic credentials in the social sciences, a refreshing sense of humor, and sincere empathy for people and their beliefs. Raised in New York, he settled in Israel more than thirty years ago. He works mostly for Palestinian tour operators who arrange visits and pilgrimages for Christians from abroad. Feldman draws on his extensive personal experience, social science research (e.g., ethnography and interviews), and the experiences of his colleagues. He truly straddles boundaries, not only between Jews and Christians, and Israelis and Palestinians, but also between the theoretical and the practical, the academic and the personal. Although he primarily guides North American and British Christians, both Catholics and Protestants (including Evangelicals), his research allows him to refer to a broader population. 
Feldman is deeply reflective about the nature of guiding work and selfreflective about his own experiences. He indicates - for me, somewhat surprisingly-that some of the Christian leaders of the groups do not want the visitors to know that the guide himself is Jewish (pp. 118-19). Other leaders encourage him to speak of his own Jewish identity, prompting some of the members of the groups to express disbelief that someone so knowledgeable about the life of Jesus would not be a Christian. He writes that he has become "a rabbi for the Gentiles" (p. 2). The division of labor between the Israeli-Jewish guide and the Christian group leader is a theme analyzed in depth.

Other topics covered include denominational differences in the itineraries and reactions to different sites, the authenticity of different narratives, the role of tips, and the role of "shtick" (gimmicks, personal references, and the like) in guiding. Feldman is probably one of the few guides who, in a chapter on tips and souvenirs, can analyze both a Mishnaic passage on tithing and the anthropological theories of Victor Turner. Feldman writes "...the transactions of pilgrimage are not just about value for money, pleasure and social status; they are profoundly colored by religious values, political conflict and East / west power relations" (p. 92).

In his "....inquiry into formation of identity in the contact zone between native and visitor, self and other" (p. 138), he deals with how the changing political and ideological contexts affect guiding at various sites (pp. 14-15.) The heart of the book is a chapter on the Separation Wall and the competing narratives of two Christian groups visiting the Holy Land, one representing the Christian Zionist perspective and the other a so-called "Living Stones" group. The former are influenced by a right-wing Jewish narrative of "Greater Israel," based on Scripture. The latter are influenced by Palestinian liberation theology and stress the plight of contemporary Palestinians more than biblical promises to the Israelites / Jews. The two groups differ in their ideologies, both theologically and politically, as well as in their itineraries. Both sides typically ignore the complexity of the issues, but in different ways. As Feldman notes, "It is rare that a pilgrimage will make efforts to present multiple points of view that risk 'confusing people with the facts" (p. 90). He sees it as one of his tasks to offer a more balanced approach.

There are some minor flaws in the book. Although Feldman uses the term "Zionism" extensively, he never actually defines it, and there seems to be some confusion with "Christian Zionism." One can certainly be critical of some Zionist historiography, as he is, without implying that Zionism as such necessitates an effacement of the Muslim or Palestinian-Arab connection with the Land. In addition, many of the interviews were conducted in 2001. That is a long time ago; a lot has changed. Also confusing is Feldman's lack of precision in describing how he has been affected as a result of guiding Christian groups, conflating changes in his Jewish and his Israeli identities. But these are more quibbles than actual criticisms. The book is recommended for anyone who has ever visited the Holy Land or worked with groups in it. 
I want to offer one bibliographical recommendation relevant to this book: Feldman calls Israel's Ben Gurion Airport a "nonplace," or a "religiously neutral postmodern transitory space" (p. 44). A book that analyzes the deeper meanings of the airport and what they demonstrate about Israeli culture is Diana Pinto, Israel Has Moved (Cambridge: Harvard Univ. Press, 2013). 